\title{
Microbially facilitated nitrogen cycling in tropical corals
}

\author{
Thomas D. Glaze $\mathbb{D}^{1 凶}$, Dirk V. Erler (DD ${ }^{1}$ and Henri. M. P. Siljanen $\mathbb{D}^{2,3}$ \\ (c) The Author(s), under exclusive licence to International Society for Microbial Ecology 2021
}

\begin{abstract}
Tropical scleractinian corals support a diverse assemblage of microbial symbionts. This 'microbiome' possesses the requisite functional diversity to conduct a range of nitrogen $(\mathrm{N})$ transformations including denitrification, nitrification, nitrogen fixation and dissimilatory nitrate reduction to ammonium (DNRA). Very little direct evidence has been presented to date verifying that these processes are active within tropical corals. Here we use a combination of stable isotope techniques, nutrient uptake calculations and captured metagenomics to quantify rates of nitrogen cycling processes in a selection of tropical scleractinian corals.

Denitrification activity was detected in all species, albeit with very low rates, signifying limited importance in holobiont $\mathrm{N}$ removal. Relatively greater nitrogen fixation activity confirms that corals are net $\mathrm{N}$ importers to reef systems. Low net nitrification activity suggests limited $\mathrm{N}$ regeneration capacity; however substantial gross nitrification activity may be concealed through nitrate consumption. Based on nrfA gene abundance and measured inorganic $\mathrm{N}$ fluxes, we calculated significant DNRA activity in the studied corals, which has important implications for coral reef $\mathrm{N}$ cycling and warrants more targeted investigation. Through the quantification and characterisation of all relevant $\mathrm{N}$-cycling processes, this study provides clarity on the subject of tropical coralassociated biogeochemical $\mathrm{N}$-cycling.
\end{abstract}

The ISME Journal (2022) 16:68-77; https://doi.org/10.1038/s41396-021-01038-1

\section{INTRODUCTION}

Scleractinian corals harbour a broad range of bacteria, archaea, fungi, viruses and protists [1-5], which participate in a variety of interspecies relationships, ranging from mutualism to parasitism [6-9]. In addition to the well-studied symbiosis with Symbiodiniaceae, microbial associates service the 'holobiont' in a variety of capacities, including biogeochemical cycling [10-12]. The current weight of evidence suggests that microbes associated with the biogeochemical cycling of nitrogen $(\mathrm{N})$ are potentially key members of tropical coral microbiomes [13, 14], though their function and impact on the coral holobiont remains ambiguous.

Coral reef systems are characterised by high primary productivity and low nutrient availability [15]. To survive chronic oligotrophy, corals rely on rapid assimilation and retention, particularly of nitrogen $(\mathrm{N})$, which is the major limiting element for primary productivity in the ocean $[16,17]$. Microbial associates with the capacity to assimilate and conserve $\mathrm{N}$ may play a major role in alleviating nutrient limitation [18, 19]. Conversely, microbes engaging in $\mathrm{N}$ release through denitrifying processes may strengthen host tolerance to nutrient replete conditions, such as those experienced during seasonal flood events [13], or help maintain favourable $\mathrm{N}$ to $\mathrm{P}$ ratio [20]. Furthermore, as the coralSymbiodiniaceae association is largely maintained through provision and limitation of $\mathrm{N}$ from host to symbiont [15, 21, 22], $\mathrm{N}$ cycling microbial associates may have the capability to reinforce and/or destabilise this relationship [13, 23].

The phylogenetic taxa and corresponding functional marker genes associated with $\mathrm{N}_{2}$ fixation, nitrification, denitrification, anammox and dissimilatory nitrate reduction to ammonia (DNRA) have all been reported within coral microbiomes [1-3, 24, 25]. With the exception of $\mathrm{N}_{2}$ fixation, our current understanding of coral-associated $\mathrm{N}$-cycling is predominantly reliant on genetic and genomics studies, with little quantification of biogeochemical fluxes presented thus far. Few studies to date have measured nitrification and denitrification rates [19, 20], and rates of DNRA and anammox remain unquantified. While $\mathrm{N}$ cycling processes have been quantified in cold-water corals [24], these organisms are physiologically and geographically distinct from tropical reef corals, and so their respective rates are unlikely to be analogous.

The coral organism is perhaps an unexpected setting to accommodate a vibrant $\mathrm{N}$-cycling community, as many microbemediated $\mathrm{N}$-cycling processes require anaerobic conditions. However, an assortment of microhabitats with disparate characteristics co-exist within the coral holobiont, providing an array of potentially suitable environments [26]. There is considerable spatial and temporal variation in $\mathrm{O}_{2}, \mathrm{pH}$, nutrient concentration and light availability within and between coral microhabitats [27-30], which is often reflected in their distinct microbial assemblages [26].

While the significance of $\mathrm{N}_{2}$ fixation is clear [31, 32], it is unknown whether other $\mathrm{N}$-cycling microbes play an active role in controlling $\mathrm{N}$ availability, or if they simply reflect opportunistic responses to favourable nutrient perturbations. Here we aimed to detect and quantify rates of denitrification, nitrification and DNRA from coral microbiomes on a tropical island system in the Great Barrier Reef. Measured rates were compared with other coral Ncycling processes including assimilation of fixed $\mathrm{N}_{2}$ hereby

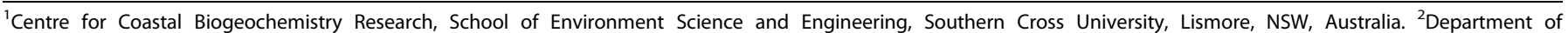
Environmental and Biological Sciences, University of Eastern Finland, Kuopio, Finland. ${ }^{3}$ Department of Ecogenomics and Systems Biology, University of Vienna, Vienna, Austria. 凶email: thomas.glaze@scu.edu.au

Received: 7 August 2020 Revised: 4 June 2021 Accepted: 8 June 2021

Published online: 5 July 2021 
referred to as diazotroph-derived nitrogen (DDN), $\mathrm{NH}_{4}^{+}$assimilation and organic/inorganic $\mathrm{N}$ fluxes.

\section{MATERIALS AND METHODS \\ Study site and collection}

This study was conducted at One Tree Island and the associated reef lagoon in the southern section of the Great Barrier Reef $\left(23^{\circ} 30.39^{\prime} \mathrm{S} 152^{\circ} 05.48^{\prime} \mathrm{E}\right)$ during November 2017. One Tree Island Reef is an emergent platform characterised by lagoonal patchwork reefs and a prominent reef crest, which isolates the lagoon for roughly $5 \mathrm{~h}$ each tide [33], elevating $\mathrm{NH}_{4}{ }^{+}$and $\mathrm{NO}_{3}{ }^{-}$ concentrations above surrounding oceanic water [34]. Nutrient concentrations were measured at $0.23 \pm 0.20-\mu \mathrm{mol} \mathrm{L}^{-1} \mathrm{NH}_{4}^{+}, 0.27 \pm 0.17-\mu \mathrm{mol} \mathrm{L}^{-1}$ $\mathrm{NO}_{3}{ }^{-}$, temperature diel variation ranged from 23 to $27^{\circ} \mathrm{C}$ and dissolved oxygen (DO) from 125 to $405 \mu \mathrm{mol} \mathrm{L}^{-1}$. Here we conducted multiple ${ }^{15} \mathrm{~N}$ tracer incubation experiments on several coral species. Terminal fragments $(4-6 \mathrm{~cm})$ were collected at 1-3-m depth from a single representative colony of six scleractinian coral species; Acropora grandis, Acropora pulchra, Porites cylindrica, Montipora digitata, Isopora elizabethensis and Isopora cuneata. Additional fragments were collected from each for DO flux, DNA extractions and surface area (SA) calculations. Detached fragments were pre-incubated for $24 \mathrm{~h}$ in 60 -L outdoor flowthrough holding tanks, covered by $15 \%$ weave shade cloths to attenuate light intensity and prevent rapid DO fluxes. Holding tanks received $5-\mathrm{L} \mathrm{min}^{-1}$ water via $50,000-\mathrm{L}$ lagoon fed headertanks. Ammonium $\left(2.07 \pm 0.80 \mu \mathrm{mol} \mathrm{L}^{-1}\right)$ and nitrate $\left(2.22 \pm 0.70 \mu \mathrm{mol} \mathrm{L}^{-1}\right)$ concentrations in the header-tank water were markedly higher than measured lagoon samples. While these values are within the reported range of DIN for OTI lagoon [33], the considerable DIN elevation relative to in situ concentrations means that $\mathrm{N}$-cycling process rates are recorded under moderately eutrophic conditions. The influence of such eutrophy on respective $\mathrm{N}$-cycling process rates fluxes is discussed below.

\section{Experimental details}

Following pre-incubation, coral fragments were divided into individual 250-mL glass jars containing unfiltered header-tank water. Jars were sealed without headspace via Teflon septa and inverted to allow maximal light penetration. Replicate fragments from the representative colony of each species were subjected to one of three enriched treatments: ${ }^{15} \mathrm{~N}_{2},{ }^{15} \mathrm{NO}_{3}{ }^{-}$ and ${ }^{15} \mathrm{NH}_{4}{ }^{+}$; each in triplicate. Additional duplicate fragments were incubated without enriched tracers to provide the isotopic baseline and background variability for flux and assimilation calculations. Further unenriched fragment laden vials (in duplicate) were incubated and measured hourly with a Hach LDO probe to track DO production and consumption. This incubation framework was conducted under both natural light and dark conditions with separate fragment batches to evaluate diel variation across $\mathrm{N}$-cycling rates. Incubation times were terminated once DO concentrations reached the limits of on-site variability, ranging from 3.75 to $5 \mathrm{~h}$ in light incubated corals, and $5-8.75 \mathrm{~h}$ in dark incubated corals. For the ${ }^{15} \mathrm{~N}-\mathrm{N}_{2}$ enrichment, the ${ }^{15} \mathrm{~N}_{2}$ dissolution technique [35] was applied, where $10 \mathrm{~mL}$ of ${ }^{15} \mathrm{~N}-\mathrm{N}_{2}$ stock solution was injected (with venting) to each $250-\mathrm{mL}$ jar. Stock solution was prepared through addition of $25-\mathrm{mL}$ pure ${ }^{15} \mathrm{~N}-\mathrm{N}_{2}$ gas (>98\% Cambridge Isotope Laboratories, lot no. l-19168A) to $500 \mathrm{~mL} 0.22-\mu \mathrm{m}$ filtered and degassed (45 min) seawater. For the ${ }^{15} \mathrm{NO}_{3}{ }^{-}$and ${ }^{15} \mathrm{NH}_{4}{ }^{+}$treatments, incubation jars received $1-\mathrm{mL}$ injections of $>98 \%{ }^{15} \mathrm{~N}-\mathrm{KNO}_{3}$ or ${ }^{15} \mathrm{~N}-\mathrm{NH}_{4} \mathrm{Cl}$ stock solutions, totalling $3 \mu \mathrm{mol} \mathrm{L} \mathrm{L}^{-1}$ of additional DIN in each respective treatment.

\section{Sampling and analysis}

Filtered water samples $(0.22 \mu \mathrm{m})$ were collected from control treatment jars prior to and post incubation, allowing characterisation of nutrient perturbations over the experimental period. Concentrations of $\mathrm{NO}_{x}\left(\mathrm{NO}_{3}{ }^{-}\right.$ $+\mathrm{NO}_{2}{ }^{-}$), $\mathrm{NH}_{4}{ }^{+}$and total dissolved $\mathrm{N}$ (TDN) were measured colorimetrically via a Lachat Quikchem 8500 Series 2 Flow Injection Analyser. As $\mathrm{NO}_{2}{ }^{-}$is negligible in reef waters, $\mathrm{NO}_{x}$ is presumed to represent $\mathrm{NO}_{3}{ }^{-}$only. Dissolved organic $\mathrm{N}(\mathrm{DON})$ was calculated as: $\mathrm{DON}=\mathrm{TDN}-\left(\mathrm{NH}_{4}^{+}+\mathrm{NO}_{x}\right)$.

Denitrification was measured as the production of ${ }^{15} \mathrm{~N}-\mathrm{N}_{2}$ in jars subjected to ${ }^{15} \mathrm{NO}_{3}{ }^{-}$or ${ }^{15} \mathrm{NH}_{4}{ }^{+}$addition. Following incubations, water samples were collected, added to duplicate $12-\mathrm{mL}$ exetainers without headspace, and killed using saturated $\mathrm{HgCl}_{2}$ solution $(20 \mu \mathrm{L} \sim 8 \% \mathrm{~W} / \mathrm{v})$. Vials were headspaced with 2-mL $\mathrm{He}$ and left to equilibrate overnight. Exetainer headspace samples $(10 \mu \mathrm{L})$ were analysed for ${ }^{15} \mathrm{~N}-\mathrm{N}_{2}$ on a Thermo Trace GC Ultra with a $25 \mathrm{~m} \times 0.32-\mathrm{mm}$ PoraPLOT Q column interfaced to a Thermo Delta V Plus isotope ratio mass spectrometer (IRMS) (precision $\pm 0.15 \%$ ). Sample gases were passed over a heated copper reduction column prior to separation on the column, reducing all $\mathrm{N}_{2} \mathrm{O}$ and $\mathrm{NO}$ present to $\mathrm{N}_{2}$. Given the high $\mathrm{m} / \mathrm{z30}$ generated during ionization in the IRMS, the production of ${ }^{30} \mathrm{~N}_{2}$ could not be accurately determined, therefore the rate of total $\mathrm{N}_{2}$ production was calculated via the production of ${ }^{29} \mathrm{~N}_{2}$ only [36] after both ${ }^{15} \mathrm{~N}_{-} \mathrm{NO}_{3}{ }^{-}$and ${ }^{15} \mathrm{~N}-\mathrm{NH}_{4}{ }^{+}$addition in the respective treatments. This approach assumes no contribution from anammox to $\mathrm{N}_{2}$ production. While we found no molecular evidence of anammox (see results), a previous study has detected $h z s A$ and $h z o$ genes within coral microbiomes [25]. The presence of anammox would overestimate total $\mathrm{N}_{2}$ production. Note that $\mathrm{N}_{2}$ production following ${ }^{15} \mathrm{~N}_{-} \mathrm{NO}_{3}{ }^{-}$addition signifies heterotrophic denitrification, while $\mathrm{N}_{2}$ production following ${ }^{15} \mathrm{~N}_{-} \mathrm{NH}_{4}{ }^{+}$ represents some combination of coupled nitrification-denitrification, and potentially $\mathrm{N}_{2} \mathrm{O}$ production via nitrifier nitrification and nitrifier denitrification.

For nitrification rates, filtered water samples $(0.22 \mu \mathrm{m})$ were collected from control and ${ }^{15} \mathrm{~N}-\mathrm{NH}_{4}{ }^{+}$treatment jars. Nitrification was determined via the production of ${ }^{15} \mathrm{~N}-\mathrm{NO}_{3}{ }^{-}$in the ${ }^{15} \mathrm{~N}_{-} \mathrm{NH}_{4}{ }^{+}$treatment [24]. The $\mathrm{N}$ isotope signature of $\mathrm{NO}_{3}{ }^{-}\left(\delta^{15} \mathrm{~N}-\mathrm{NO}_{3}{ }^{-}\right)$was determined via the denitrifier technique [37], which converts $\mathrm{NO}_{3}{ }^{-}$to $\mathrm{N}_{2} \mathrm{O}$. The $\mathrm{N}$ isotope signature $\delta^{15} \mathrm{~N}\left(\left(\delta^{15} \mathrm{~N}\right.\right.$ (in permil, \%o $)=1000^{*}\left(\left({ }^{15} \mathrm{~N} /{ }^{14} \mathrm{~N}\right)_{\text {sample }} /\left({ }^{15} \mathrm{~N} /{ }^{14} \mathrm{~N}\right)_{\text {reference }}-1\right)$, where the ${ }^{15} \mathrm{~N} /{ }^{14} \mathrm{~N}$ reference is $\mathrm{N}_{2}$ in air). Liberated $\mathrm{N}_{2} \mathrm{O}$ was purified in liquid $\mathrm{N}_{2}$ with a custom-built purge and trap system and the $\delta^{15} \mathrm{~N}-\mathrm{N}_{2} \mathrm{O}$ was measured via a Thermo Delta V Plus IRMS coupled to a Thermo Fisher GasBench II. The $\delta^{15} \mathrm{~N}-\mathrm{NO}_{3}{ }^{-}$values were standardised against IAEA-NO-3 $\left(\delta^{15} \mathrm{~N}^{-N O_{3}}{ }^{-}\right.$of $4.7 \%$ ) with an analytical precision of $0.2 \%$. Nitrification values represent the appearance of ${ }^{15} \mathrm{~N}^{-\mathrm{NO}_{3}}{ }^{-}$, signifying net nitrification, as $\mathrm{NO}_{3}{ }^{-}$subsequently assimilated or immobilized remains undetected.

Coral fragments were rinsed with header-tank water, shaken dry, weighed and frozen at $-20^{\circ} \mathrm{C}$. To determine the respective assimilation rates of DDN and $\mathrm{NH}_{4}^{+}$assimilation, fragments were ground to a powder with a stainless-steel mortar and pestle, freeze dried and weighed (100 mg) into tin capsules for bulk $\delta^{15} \mathrm{~N}$ analysis. This was performed via elemental analysis on a Thermo Finnigan Flash EA 1112 coupled to a Thermo Delta V Plus IRMS via a Thermo Conflo III, providing $\delta^{15} \mathrm{~N}$ (precision $\pm 0.15 \%$ ) and $\% \mathrm{~N}$ (precision $\pm 1 \%$ coefficient of variation). Respective rates of DDN and $\mathrm{NH}_{4}{ }^{+}$assimilation were determined using the difference in ${ }^{15} \mathrm{~N}$ content between control coral fragments and those exposed to ${ }^{15} \mathrm{~N}_{2}$ or ${ }^{15} \mathrm{NH}_{4}^{+}$. Volumetric rate of DDN and $\mathrm{NH}_{4}{ }^{+}$assimilation $(\rho)$ was presented as $\mu \mathrm{mol}$ $\mathrm{m}^{-2} \mathrm{~d}^{-1}$, calculated using:

$\rho=\left[\frac{A_{S}-A_{C}}{\left(A_{i}-A_{C}\right) t_{\text {inc }} S}\right] \times \overline{P N} \times 24 \times 10^{4}$

where $A_{s}={ }^{15} \mathrm{~N}$ Atom $\%$ enriched fragments, $A_{c}={ }^{15} \mathrm{~N}$ Atom\% of natural abundance control fragments, $A_{i}={ }^{15} \mathrm{~N}$ Atom $\%$ initial label concentration of either ${ }^{15} \mathrm{NH}_{4}{ }^{+}$or ${ }^{15} \mathrm{~N}_{2}, t_{\text {inc }}=$ incubation time $(\mathrm{h}), \overline{P N}=\mu \mathrm{mol}$ particulate $\mathrm{N}$ per fragment (assuming no change) and $S=$ fragment $S A\left(\mathrm{~cm}^{2}\right)$. Atom $\%(A)$ and particulate nitrogen $(P N)$ calculations were derived from Montoya [38].

$A=100 \times\left[\frac{\left(10^{-3} \delta^{15} N+1\right)\left({ }^{15} N /{ }^{14} N\right)_{\text {atmosphere }}}{1+\left(10^{-3} \delta^{15} N+1\right)\left({ }^{15} N /{ }^{14} N\right)_{\text {atmosphere }}}\right]$ and $\overline{P N}=\left[\frac{W \times N}{100}\right] \times\left[\frac{10^{6}}{14}\right]$

where $W$ is the fragment weight $(\mathrm{g})$ and $N$ is the fragment $\% \mathrm{~N}$. Nitrogen fixed and subsequently released as DIN, DON or suspended particles was not evaluated.

DNRA process rates were not measured directly, instead we evaluated potential DNRA using an $\mathrm{NO}_{3}{ }^{-}$mass balance model for both light and dark scenarios, according to the following:

$\mathrm{NO}_{3}{ }^{-}$assimilation $=\mathrm{NO}_{3}{ }^{-}$net flux + Gross nitrification-DNRA

And therefore:

DNRA $=\mathrm{NO}_{3}{ }^{-}$net flux + Gross nitrification $-\mathrm{NO}_{3}{ }^{-}$assimilation

This formula accounts for all possible pathways of $\mathrm{NO}_{3}{ }^{-}$flux. Nitrate net flux is calculated using the change in $\mathrm{NO}_{3}{ }^{-}$concentration over the incubation period. Gross nitrate assimilation was not measured directly but can be estimated using measured $\mathrm{NH}_{4}{ }^{+}$assimilation data (via ${ }^{15} \mathrm{NH}_{4}{ }^{+}$ amendment) and the ratio of $\mathrm{NH}_{4}{ }^{+}$to $\mathrm{NO}_{3}{ }^{-}$assimilation (Eq. (6)).

DNRA $=\mathrm{NO}_{3}{ }^{-}$net flux + Gross nitrification $-\left(\mathrm{NH}_{4}{ }^{+}\right.$assimilation $\left./ R\right)$

where $R$ is the $\mathrm{NH}_{4}{ }^{+}: \mathrm{NO}_{3}{ }^{-}$assimilation ratio. $R$ can be expressed as \%DIN, 

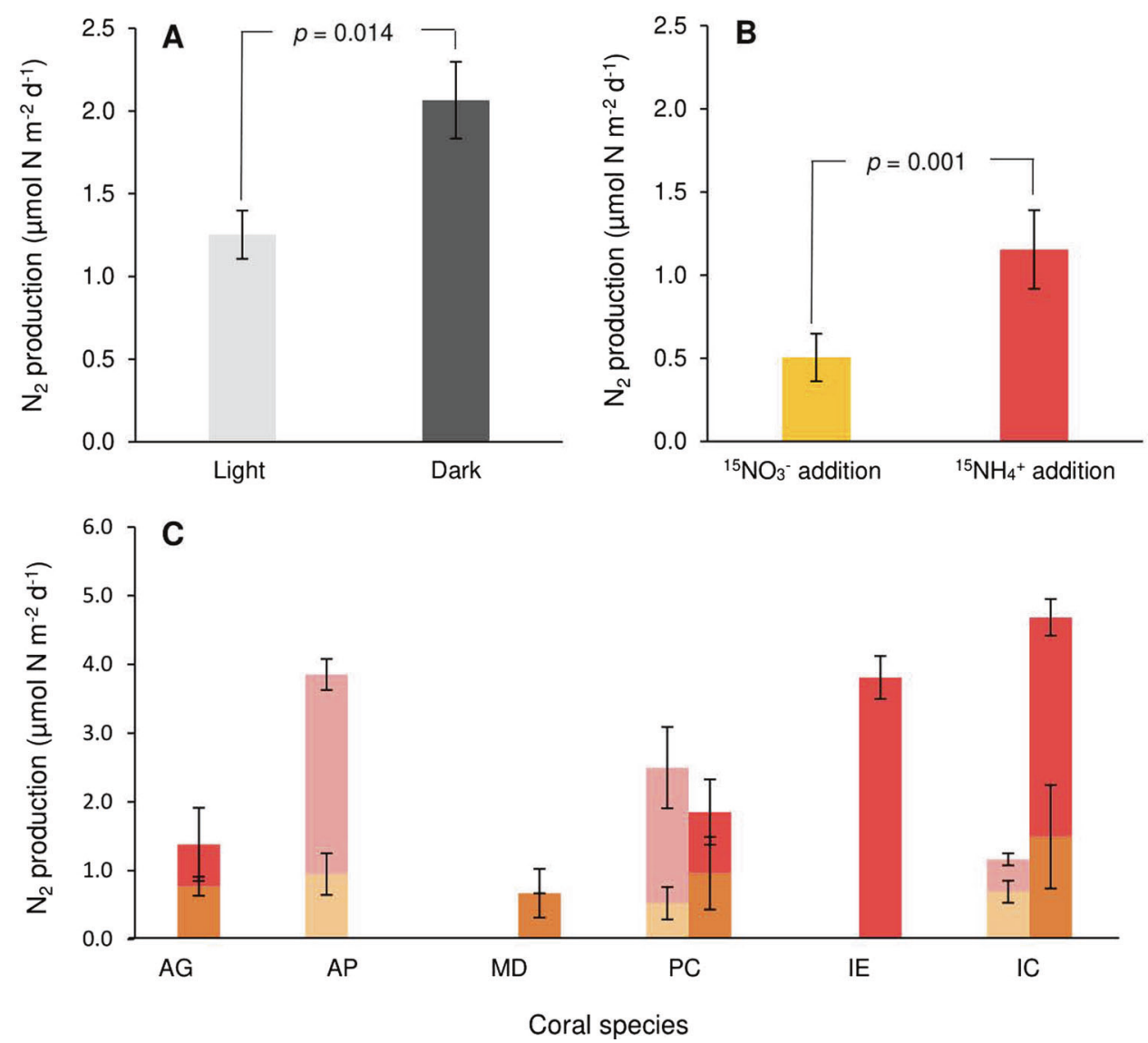

Fig. 1 Total $\mathrm{N}_{2}$ production ( $\mu \mathrm{mol} \mathrm{N} \mathrm{m}{ }^{-2}$ coral surface area $\mathrm{d}^{-1}$ ) in ${ }^{15} \mathrm{NO}_{3}{ }^{-}$and ${ }^{15} \mathrm{NH}_{4}{ }^{+}$treatments. A Interspecies mean $\mathrm{N}_{2}$ production across light and dark incubations (accumulated over treatments). B Interspecies mean $\mathrm{N}_{2}$ production following ${ }^{15} \mathrm{NO}_{3}{ }^{-}$and ${ }^{15} \mathrm{NH}_{4}^{+}$treatments averaged over light/dark incubations. $\mathrm{C} \mathrm{N}_{2}$ production by coral species. Orange/yellow hues represent ${ }^{15} \mathrm{NO}_{3}{ }^{-}$addition, red/pink hues represent ${ }^{15} \mathrm{NH}_{4}^{+}$addition. Light hues denote light incubated corals. Dark hues denote dark incubated corals. All error bars as standard error.

representing $\mathrm{NH}_{4}{ }^{+}$assimilation as a percentage of total DIN assimilation

$\%$ DIN $=\mathrm{NH}_{4}{ }^{+}$assim. $/\left(\mathrm{NH}_{4}{ }^{+}\right.$assim. $+\left(\mathrm{NH}_{4}{ }^{+}\right.$assim. $\left.\left./ R\right)\right) \times 100$

Gross nitrification was represented as a percentage of $\mathrm{NH}_{4}{ }^{+}$assimilation. A matrix of potential DNRA rates was then calculated and constrained using literature values of gross nitrification [19] and conservative estimates of $\mathrm{NO}_{3}{ }^{-}$assimilation [39, 40].

All $\mathrm{N}$-cycling rates were normalised to coral SA with units of $\mu \mathrm{mol} N$ $\mathrm{m}^{-2} \mathrm{~d}^{-1}$. We determined SA through 3D-scanning of additional fragments from each tested colony $(n=6)$ using a David SLS-3 laser scanner, quantified using Autodesk Netfabb Premium meshing software. Average $\mathrm{SA} /$ weight ratios from these representatives were utilized as speciesspecific SA/weight ratios and applied to weighed experimental fragments.

\section{Captured metagenomics}

We used $P$. cylindrica as a model species to characterise both the abundance and species composition of nitrogen cycling functional marker genes related to nitrogen fixation, nitrification, denitrification, anammox and DNRA through the use of a custom designed captured metagenomics tool. Two $P$. cylindrica fragments were collected and immediately frozen $\left(-20^{\circ} \mathrm{C}\right)$, ground and homogenized in liquid $\mathrm{N}_{2}$ with a stainless-steel mortar and pestle. DNA extractions were conducted on the resultant slurries using Qiagen DNeasy Powerbioflim minikit. DNA concentration and purity were quantified using a Qubit fluorometer and Nanodrop 2000c spectrophotometer, respectively. We utilized the NimbleGen SeqCap EZ protocol by Roche NimbleGen inc. The probe selection and validation are described in Supplementary methods, and bioinformatic data analysis was conducted as outlined in Aalto [41]. The relative frequency and taxonomic breakdown of captured gene hits are outlined in Supplementary table. The metagenomic data are deposited to the SRA database under the BioProject link PRJNA685986.

\section{Data analysis}

Statistical analysis was conducted using Primer 7 software with the PERMANOVA + add on. We conducted two factor PERMANOVAs based on Euclidean distance on a range of parameters $\left(\mathrm{N}_{2}\right.$ production, net nitrification, DDN assimilation, $\mathrm{NH}_{4}{ }^{+}$assimilation and net fluxes of $\mathrm{NH}_{4}{ }^{+}$, $\mathrm{NO}_{3}{ }^{-}$and $\mathrm{DON}$ ) to determine the influence of light regime and coral species. To conform datasets to normality log 10 transformations were conducted. Type III (partial) sum of squares with permutation of residuals was used under a reduced model (999 permutations). Pairwise comparisons were conducted to determine the interaction between independent variables.

\section{RESULTS}

Evidence for active denitrification and nitrification in tropical coral microbiomes

Denitrification, defined as the cumulative release of $\mathrm{N}_{2}, \mathrm{~N}_{2} \mathrm{O}$ and $\mathrm{NO}$, was recorded in all tropical coral species tested, $\bar{x}=1.56 \mu \mathrm{mol}$ $\mathrm{N} \mathrm{m}^{-2} \mathrm{~d}^{-1}$. Corals incubated under dark conditions registered greater $\mathrm{N}_{2}$ production $\left(\bar{x}=2.07 \mu \mathrm{mol} \mathrm{N} \mathrm{m} \mathrm{N}^{-2} \mathrm{~d}^{-1}\right)$, than those under light conditions $\left(\bar{x}=1.25 \mu \mathrm{mol} \mathrm{N} \mathrm{m}{ }^{-2} \mathrm{~d}^{-1}, p=0.014\right)$ (Fig. 1A).

$\mathrm{N}_{2}$ produced following ${ }^{15} \mathrm{NO}_{3}{ }^{-}$addition $\left(0.50 \mu \mathrm{mol} \mathrm{N} \mathrm{m}{ }^{-2} \mathrm{~d}^{-1}\right)$ was considerably lower than from ${ }^{15} \mathrm{NH}_{4}^{+}$addition $(1.15 \mu \mathrm{mol} N$ $\mathrm{m}^{-2} \mathrm{~d}^{-1}, p=0.001$ ) (Fig. 1B), though this varied greatly within and between tested colonies (Fig. 1C). Total $\mathrm{N}_{2}$ production was negligible in comparison with other holobiont $\mathrm{N}$ release mechanisms such as estimated $\mathrm{NH}_{4}{ }^{+}$release $\left(\bar{x}=1993.4 \mu \mathrm{mol} \mathrm{N} \mathrm{m}{ }^{-2} \mathrm{~d}^{-1}\right)$ and net DON flux $\left(\bar{x}=448.5 \mu \mathrm{mol} \mathrm{N} \mathrm{m}{ }^{-2} \mathrm{~d}^{-1}\right)$, representing just $0.07 \%$ TDN release. 

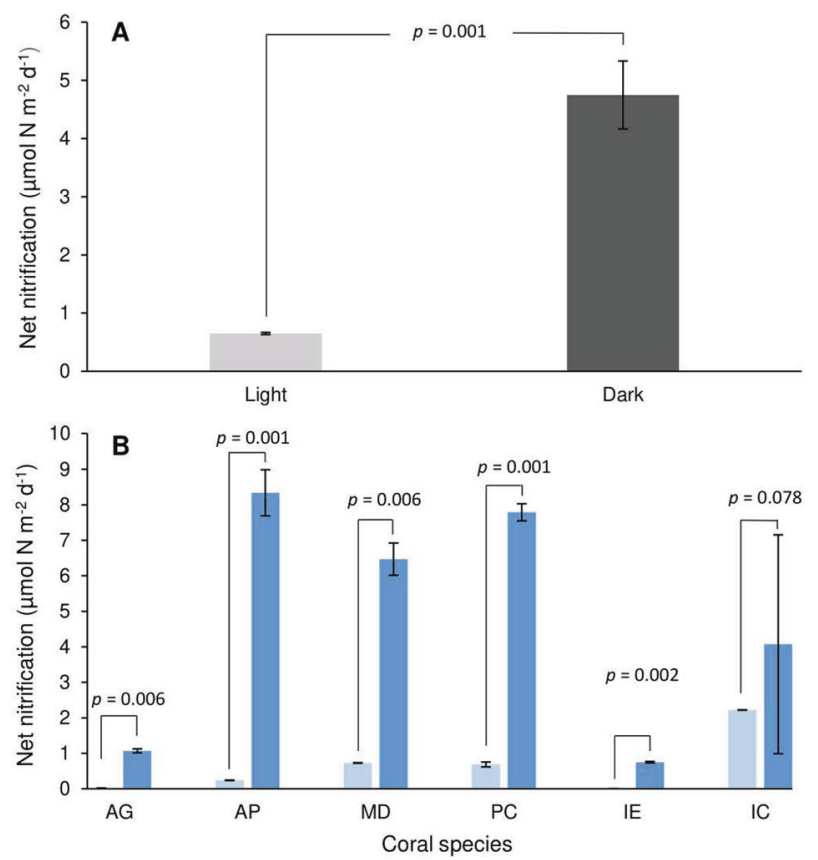

Fig. 2 Net nitrification rate measurements. A Mean interspecies net nitrification in light and dark incubations. B Net nitrification by species. Light hues represent light incubated corals. Dark hues represent dark incubated corals. Error bars as standard error.

Net nitrification, identified as the appearance of ${ }^{15} \mathrm{~N}^{-\mathrm{NO}_{3}}{ }^{-}$in ${ }^{15} \mathrm{~N}^{-\mathrm{NH}_{4}}{ }^{+}$labelled incubations, was observed in all tested colonies, $\bar{x}=2.70 \mu \mathrm{mol} \mathrm{N} \mathrm{m} \mathrm{m}^{-2} \mathrm{~d}^{-1}$. Significantly higher rates were recorded under dark $\left(\bar{x}=4.75 \mu \mathrm{mol} \mathrm{N} \mathrm{m}{ }^{-2} \mathrm{~d}^{-1}\right)$ than light incubated corals $\left(\bar{x}=0.65 \mu \mathrm{mol} \mathrm{N} \mathrm{m}{ }^{-2} \mathrm{~d}^{-1}, p<0.001\right)$ (Fig. 2A), which was observed in all species but $l$. cuneata $(p=0.078)$ (Fig. 2B). While all species presented measurable net nitrification rates under both light and dark conditions, significant interspecies differences were observed $(p<0.009)$. Despite modest net nitrification rates, the highly enriched $\delta^{15} \mathrm{~N}^{-N}{ }_{3}{ }^{-}$of the remaining $\mathrm{NO}_{3}{ }^{-}$pool indicates considerably greater gross nitrification activity. The $\delta^{15} \mathrm{~N}-\mathrm{NO}_{3}{ }^{-}$ shows elevated enrichment from dark ( $\bar{x}=325.97 \%$ o) than light incubations $(\bar{x}=40.55 \%$ ), despite the longer incubation times depleting the nitrate concentration. This suggests that dark upregulated net nitrification accurately reflects diel patterns in gross nitrification, and is not simply an artefact of disparate $\mathrm{NO}_{3}{ }^{-}$ assimilation rates. In the absence of gross nitrification measurements, we accept the rates of corals incubated at One Tree Island may be within the range reported by Wafar et al. (1990) [19]. For dark incubations, at $\approx 17 \%$ of $\mathrm{NH}_{4}{ }^{+}$assimilation, this would equal $\bar{x}=196.6 \mu \mathrm{mol} \mathrm{N} \mathrm{m}{ }^{-2} \mathrm{~d}^{-1}$. Assuming $\delta^{15} \mathrm{~N}^{-\mathrm{NO}_{3}}{ }^{-}$enrichment scales linearly with gross nitrification between light and dark incubations, daytime gross nitrification can then be estimated via

$\mathrm{GNIT}_{\text {light }}=\mathrm{GNIT}_{\text {dark }} /\left(\frac{\delta^{15} \mathrm{NNO}_{3}{ }^{-} \text {dark }}{\delta^{15} \mathrm{NNO}_{3}{ }^{-} \text {light }}\right)$

where $\mathrm{GNIT}_{\text {light }}=$ light gross nitrification, $\mathrm{GNIT}_{\text {dark }}=$ dark gross

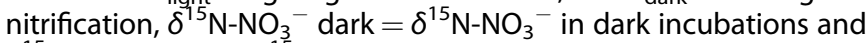

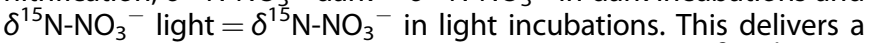
rough gross nitrification estimation of $24.5 \mu \mathrm{mol} \mathrm{N} \mathrm{m} \mathrm{m}^{-2} \mathrm{~d}^{-1}$.

\section{Other $\mathrm{N}$-cycling pathways}

Assimilation of $\mathrm{N}$ via $\mathrm{N}_{2}$ fixation (DDN) occurred in all tested colonies, with an interspecies mean of $172.8 \mu \mathrm{mol} \mathrm{N} \mathrm{m}{ }^{-2} \mathrm{~d}^{-1}$. Across species, assimilation of DDN was significantly greater in dark $\left(\bar{x}=227.8 \mu \mathrm{mol} \mathrm{N} \mathrm{m}{ }^{-2} \mathrm{~d}^{-1}\right)$ than light incubated corals $\left(\bar{x}=117.9 \mu \mathrm{mol} \mathrm{N} \mathrm{m}{ }^{-2} \mathrm{~d}^{-1}, p=0.014\right)$ (Fig. $\left.3 \mathrm{~A}\right)$; however, within
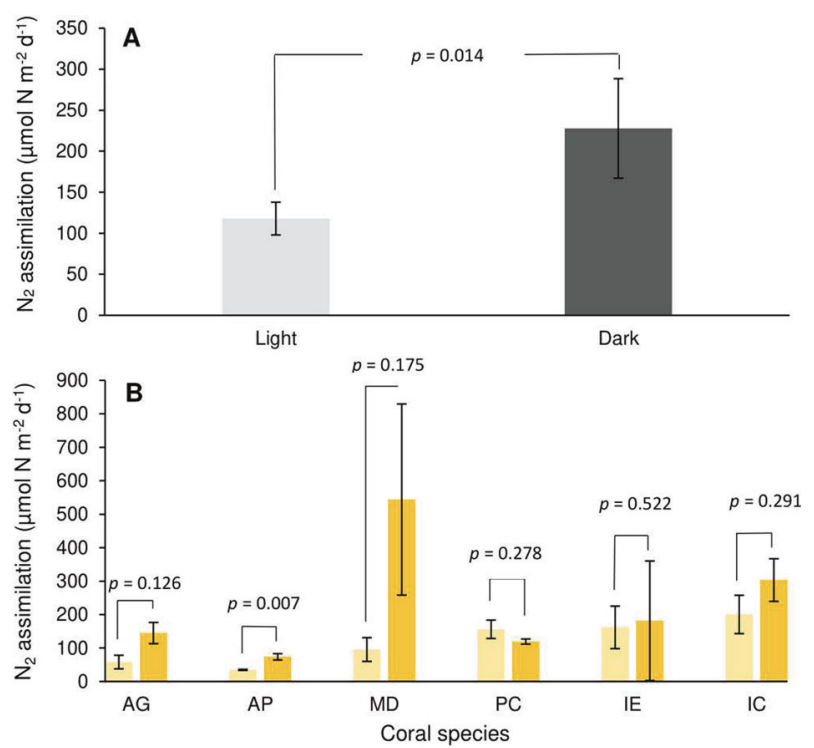

Fig. 3 Diazotroph-derived nitrogen (DDN) assimilation rates. A Mean interspecies DDN assimilation during light and dark scenarios. B DDN assimilation across coral species. Light hues represent light incubated corals. Darker hues represent dark incubated corals. Error bars as standard error.

species, this tendency was only significant in $A$. pulchra $(p=0.007)$ (Fig. 3B). We find significant interspecies variability in DDN assimilation ( $p=0.012)$.

$\mathrm{N}_{2}$ fixation represents a non-negligible $\mathrm{N}$ source to the coral $\mathrm{N}$ budget, where DDN equates to $7.6 \%$ of the quantity $\mathrm{N}-\mathrm{NH}_{4}{ }^{+}$ assimilated. The relative contribution of DDN, when compared with $\mathrm{NH}_{4}^{+}$assimilation as a nutritional component was much greater under dark (19.7\%) than light incubations (3.46\%), and mostly consistent across species $(10.5 \pm 0.7 \%)$ with the exception of $A$. pulchra (1.4\%). Nitrogen gained through DDN assimilation outpaced nitrogen lost through $\mathrm{N}_{2}$ production by a factor of 104:1, signifying corals are net importers of $\mathrm{N}$ to reef systems. This was consistent across both light (94:1) and dark conditions (110:1) but variable between species, ranging from $A$. pulchra (28:1) to $M$. digitata (954:1). Note that this study did not measure gross $\mathrm{N}_{2}$ fixation, as fixed ${ }^{15} \mathrm{~N}$ residues released in the form of DIN, DON and suspended particles were not evaluated. This ratio of DDN assimilation: $\mathrm{N}_{2}$ release therefore likely underestimates the total net import of $\mathrm{N}$ to reef systems from coral organisms.

All measured coral colonies assimilated $\mathrm{NH}_{4}{ }^{+}$into biomass, $\bar{x}=$ $2283.5 \mu \mathrm{mol} \mathrm{N} \mathrm{m} \mathrm{m}^{-1}$, with more rapid assimilation occurring under light $\left(\bar{x}=3410.2 \mu \mathrm{mol} \mathrm{N} \mathrm{m}{ }^{-2} \mathrm{~d}^{-1}\right)$ than dark incubations $(\bar{x}=$ $\left.1156.3 \mu \mathrm{mol} \mathrm{N} \mathrm{m} \mathrm{d}^{-1}, \quad p<0.001\right)$, and significant differences between species $(p<0.001)$. Net uptake of $\mathrm{NH}_{4}{ }^{+}$was recorded across all species $\left(\bar{x}=289.8 \mu \mathrm{mol} \mathrm{N} \mathrm{m}{ }^{-2} \mathrm{~d}^{-1}\right)$, where apparent differences between light $\left(\bar{x}=392.5 \mu \mathrm{mol} \mathrm{N} \mathrm{m}{ }^{-2} \mathrm{~d}^{-1}\right)$ and dark incubations $\left(\bar{x}=187.2 \mu \mathrm{mol} \mathrm{N} \mathrm{m} \mathrm{N}^{-2} \mathrm{~d}^{-1}\right)$ were statistically insignificant $(p=0.084)$. The net flux of $\mathrm{NH}_{4}{ }^{+}$represents only $7-20 \%$ of measured $\mathrm{NH}_{4}^{+}$assimilation values across species, signifying considerable $\mathrm{NH}_{4}{ }^{+}$release and assimilation occur concurrently. Assuming this is not a methodological artefact, combined $\mathrm{NH}_{4}^{+}$ release mechanisms $\left(\mathrm{NH}_{4}^{+}\right.$waste/mineralisation/DNRA) must account for the remaining $80-90+\%$. Net uptake of $\mathrm{NO}_{3}{ }^{-}$was also recorded across all species $\left(\bar{x}=453.3 \mu \mathrm{mol} \mathrm{N} \mathrm{m}{ }^{-2} \mathrm{~d}^{-1}\right)$ with greater uptake occurring in dark $\left(\bar{x}=591.1 \mu \mathrm{mol} \mathrm{N} \mathrm{m} \mathrm{N}^{-2} \mathrm{~d}^{-1}\right)$ over light incubations $\left(\bar{x}=316.7 \mu \mathrm{mol} \mathrm{N} \mathrm{m} \mathrm{d}^{-2} \mathrm{~d}^{-1} \quad p=0.001\right)$. All species exhibited net DON release, $\left(\bar{x}=448.5 \mu \mathrm{mol} \mathrm{N} \mathrm{m}{ }^{-2} \mathrm{~d}^{-1}\right)$ with significant variation within and between tested colonies yet no discernible differences between light $\left(\bar{x}=426.2 \mu \mathrm{mol} \mathrm{N} \mathrm{m} \mathrm{d}^{-1}\right)$ and dark conditions $\left(\bar{x}=448.5 \mu \mathrm{mol} \mathrm{N} \mathrm{m}{ }^{-2} \mathrm{~d}^{-1}, p=0.668\right)$. The net flux 


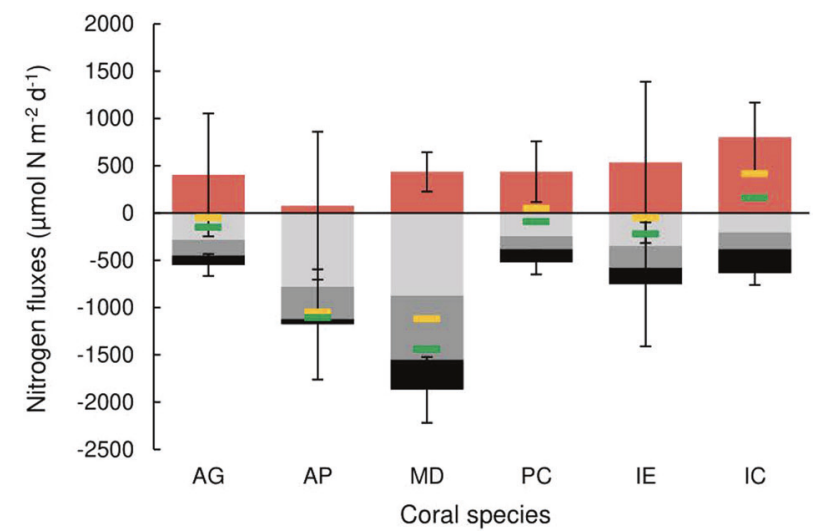

Fig. 4 Net fluxes of DON (red), $\mathrm{NO}_{3}{ }^{-}$(light grey), $\mathrm{NH}_{4}{ }^{+}$(dark grey) and $\mathbf{N}_{\mathbf{2}}$ (black) within the coral holobiont. Positive values denote net positive flux (release), negative values denote net negative flux (uptake). Yellow markers denote dissolved $\mathrm{N}$ flux excluding DDN, green markers denote dissolve $\mathrm{N}$ flux including DDN. Error bars as standard error.

of $\mathrm{N}_{2}$, calculated as: $\mathrm{N}_{2}$ net flux $=\mathrm{DDN}$ assimilation $-\mathrm{N}_{2}$ production accounts for a considerable proportion of the coral dissolved $\mathrm{N}$ budget, equivalent to $23 \%$ of net DIN flux (range $=4.7-65 \%$ ) and can modify the dissolved $\mathrm{N}$ budget status from net release to net uptake (Fig. 4).

\section{DNRA activity}

The estimation of DNRA activity is largely influenced by the ratio of $\mathrm{NH}_{4}{ }^{+}$assimilation to $\mathrm{NO}_{3}{ }^{-}$assimilation. To date, the only studies to have tracked gross uptake of both $\mathrm{NH}_{4}{ }^{+}$and $\mathrm{NO}_{3}$ within one coral species show that $\mathrm{NH}_{4}{ }^{+}$assimilation is 1-2 orders of magnitude higher than $\mathrm{NO}_{3}{ }^{-}[39,40]$, meaning $\mathrm{NH}_{4}{ }^{+}$accounts for $90-99 \%$ of total DIN assimilation. Assuming this tendency applies to the current study, and using net nitrification values recorded herein $\left(<1 \% \mathrm{NH}_{4}^{+}\right.$assimilation) as inputs for gross nitrification in the $\mathrm{NO}_{3}{ }^{-}$mass balance model, DNRA activity equates to $\sim 460-600 \mu \mathrm{mol} \mathrm{N} \mathrm{m}{ }^{-2} \mathrm{~d}^{-1}$ in dark incubations (Fig. 5A). Actual gross nitrification rates are likely to be much higher, as net nitrification rates do not account for assimilation of nitrified $\mathrm{NO}_{3}{ }^{-}$. Using the only quantified gross nitrification rates in the literature at $\approx 17 \%$ of $\mathrm{NH}_{4}{ }^{+}$assimilation [19] as inputs instead, DNRA activity under dark conditions ranges from 660 to $780 \mu \mathrm{mol} \mathrm{N} \mathrm{m}{ }^{-2} \mathrm{~d}^{-1}$ (Fig. 5A). Under all available combinations of literature $\mathrm{NH}_{4}^{+}$to $\mathrm{NO}_{3}{ }^{-}$assimilation ratios and nitrification rates, dark associated DNRA presents a potentially significant pathway of nutrient retention. Daytime DNRA is more difficult to estimate, although ostensibly less than under dark conditions. Measured net

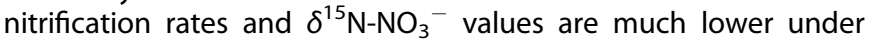
light than dark conditions, and $\mathrm{NH}_{4}^{+}$assimilation is already an order of magnitude greater than $\mathrm{NO}_{3}{ }^{-}$net flux. Using either our measured net nitrification values or previously outlined extrapolations of daytime gross nitrification (see: 'Results', nitrification) as gross nitrification inputs, estimated daytime DNRA remains in the range of $0-300 \mu \mathrm{mol} \mathrm{N} \mathrm{m}{ }^{-2} \mathrm{~d}^{-1}$ (Fig. 5B).

\section{Captured metagenomics}

The results from the captured metagenomics analysis of $P$. cylindrica largely align with, and contextualise the biogeochemical evidence of coral $\mathrm{N}$-cycling, yet also present additional lines of enquiry. The captured metagenomic analysis did not detect functional genes associated with anammox (hzoA) or ammonia oxidation $(a m o A, h a o)$, yet found some nitrite oxidizing functional maker genes ( $n x r B)$, comprising $3.6 \%$ of $\mathrm{N}$-cycling gene hits (Fig. $6 \mathrm{~A}$ ). A high proportion of captured hits were nitrate reduction genes, napA (29.4\%), and narG (4.1\%) (Fig. 6A). While these genes conduct
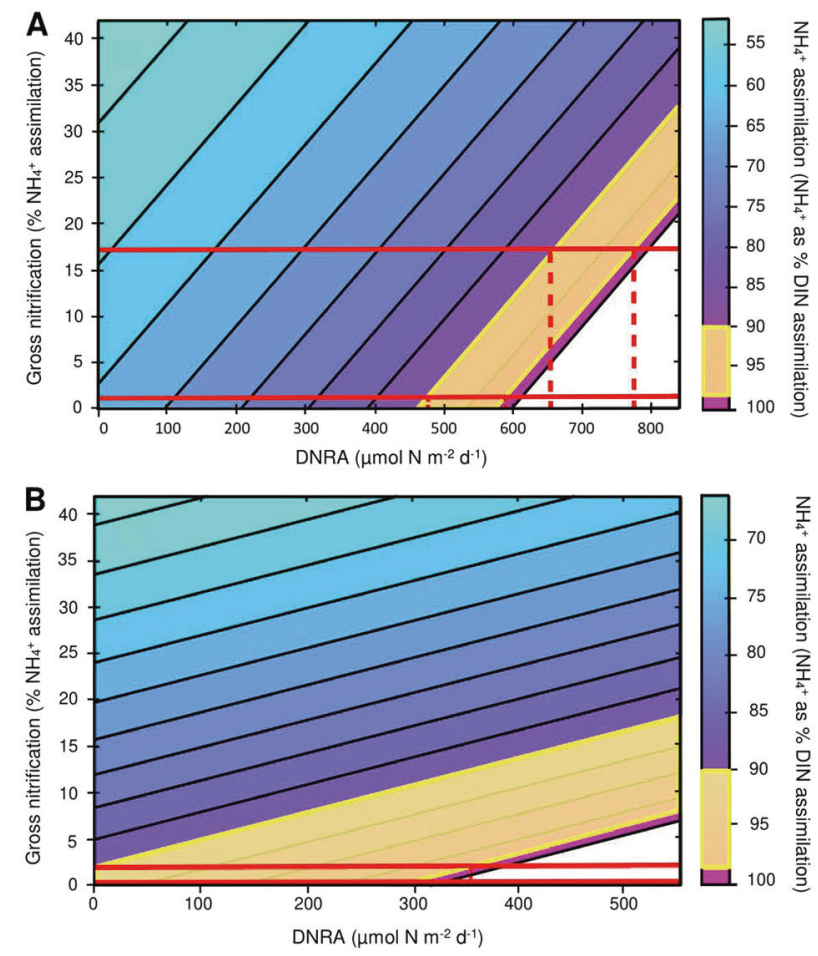

Fig. $5 \mathrm{NO}_{3}{ }^{-}$mass balance models depicting potential DNRA activity. These models estimate DNRA ( $x$-axis) over a range of gross nitrification (y-axis) and $\mathrm{NH}_{4}{ }^{+}: \mathrm{NO}_{3}{ }^{-}$assimilation ratios (secondary axis). The ratio of $\mathrm{NH}_{4}{ }^{+}: \mathrm{NO}_{3}{ }^{-}$assimilation is represented using $\mathrm{NH}_{4}{ }^{+}$ as $\%$ assimilation. Yellow bars highlight the probable range of $\% \mathrm{DIN}$ $[39,40]$. Red solid lines represent the range of likely gross nitrification estimates [19]. Red dashed lines illustrate estimated DNRA under various \%DIN and gross nitrification scenarios. A DNRA activity under dark conditions. B DNRA activity under light conditions.

the initial and rate-limiting step of both denitrification and DNRA, the major taxonomic groups identified here for nitrate reduction do not possess the requisite enzymatic machinery for denitrification. Microbes identified in captured napA hits were dominated by Vibrionales, which generally possess nrfA and not nirS/nirK [42] permitting $\mathrm{NO}_{2}{ }^{-}$reduction to $\mathrm{NH}_{3}$, but not $\mathrm{NO}$, thereby performing DNRA under $\mathrm{O}_{2}$ limitation (Fig. 6B). Microbes identified in captured narG hits exhibit diverse nitrate reduction pathways, including; nitrate respiration, DNRA, coupled nitrification-denitrification and canonical denitrification. Captured nrfA hits represent $12.1 \%$ total $\mathrm{N}$-cycling genes, and were entirely dominated by Vibrionales, primarily of the genus Vibrio. The remaining denitrifying marker genes had low relative concentrations, with nirS, nirk, norB and nos $Z$ comprising $2.8 \%, 1.3 \%, 0 \%$ and $5.2 \%$ of $\mathrm{N}$-cycling gene hits, respectively (Fig. 6A). Each of these gene pathways were dominated by distinct clades (Pseudomonadales, Rhodobacterales and Rhizobiales) (Fig. 6C). Taken together, this suggests DNRA and not denitrification is likely the dominant dissimilatory nitrate reduction pathway within the microbiome of $P$. cylindrica. At $40.1 \%$ of total $\mathrm{N}$-cycling gene hits, the relative abundance of nifH provides further evidence that this process contributes significantly to the coral N-cycle (Fig. 6A). Captured nifH hits contained considerable species, order and class diversity, albeit dominated by Rhizobiales and Rhodobacterales lineages (Fig. 6C). We recognise that the $P$. cylindrica hologenome may exhibit distinct structural and functional differences to the remaining species, which are all representatives of Acroporidae. It is that with this in mind, we advise caution in directly attributing biogeochemical fluxes to specific microbial taxa across all studied species. 
A

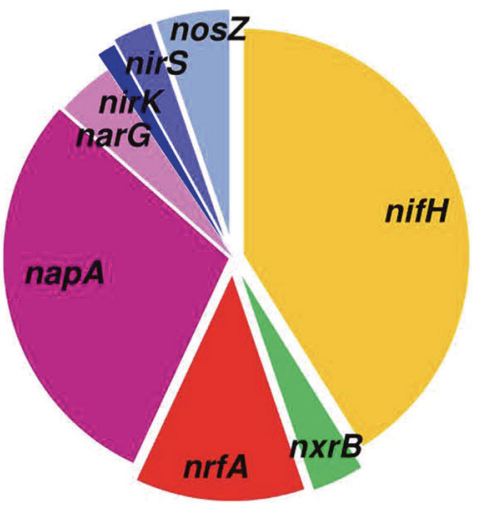

C

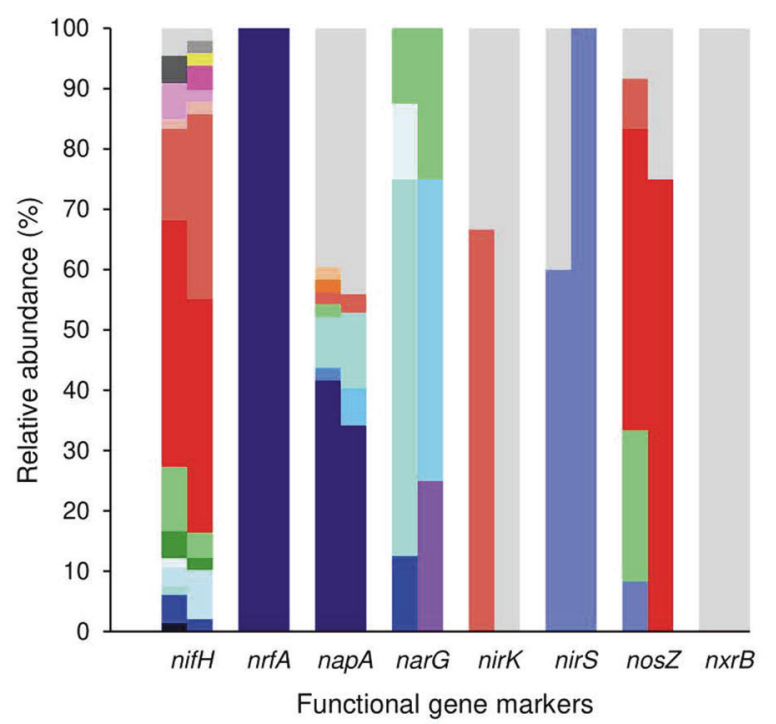

Functional gene markers

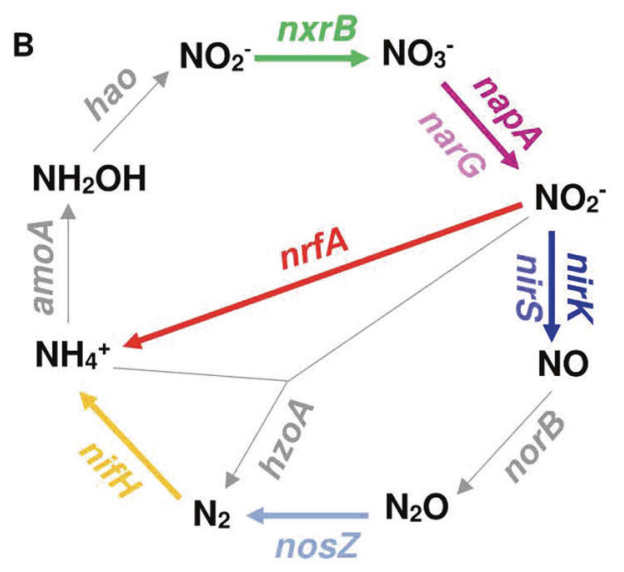

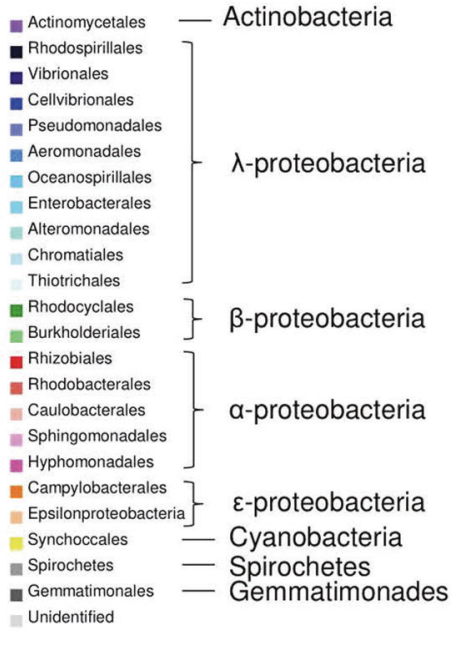

Fig. 6 Captured metagenomics functional marker gene hits. A Specific N-cycling gene hits as proportion of total captured N-cycling genes. Functional marker gene encoding as follows: nitrogen fixation-yellow, nitrite oxidation (nitrification) - green, nitrite reduction (DNRA)-red, nitrate reduction (DNRA/denitrification)-purple, $\mathrm{NO} / \mathrm{N}_{2} \mathrm{O} / \mathrm{N}_{2}$ reduction (denitrification)-blue. B Process pathways for various $\mathrm{N}$-cycling functional genes. Grey arrows represent genes not detected in P.cylindrica. C Class and order diversity of captured N-cycling genes hits, and relative abundance of functional marker genes. Both fragments are represented via split bars.

\section{DISCUSSION}

Based on the prevalence of the associated microorganisms and relevant functional genes, tropical coral microbiomes are postulated to process $\mathrm{N}$ through a variety of microbially facilitated pathways $[3,25,43,44]$. To date many of these pathways have not been adequately quantified, and as such their relevance at the organism and ecosystem scale is largely unknown [13]. Below we discuss the presence of key microbial $\mathrm{N}$-cycling processes operating within the holobiont including denitrification, nitrification, $\mathrm{N}_{2}$ fixation and DNRA.

\section{Denitrification and nitrification}

Production of $\mathrm{N}_{2}$ was recorded in all species tested at One Tree Island. Denitrification rates were of comparable magnitude to those of previous tropical coral measurements $[20,45]$ and also those of the cold-water coral Lophelia pertusa [24], suggesting that denitrification is a ubiquitous feature of coral microbiomes, irrespective of physiology and habitat. Previous molecular studies confirm that denitrifying organisms reside in coral mucus [46], tissue [44] and speculatively within gastric cavities [28]. Denitrification activity was hypothesised to upregulate during the night, when depleted $\mathrm{O}_{2}$ boundary conditions provide favourable environmental settings for anaerobic processes [46, 47]. While our interspecies mean does show dark upregulation (Fig. 1A), this trend is not observed across all species (Fig. 1C). Similarly, while $\mathrm{NH}_{4}{ }^{+}$is the preferred substrate for $\mathrm{N}_{2}$ production (Fig. 1B), this varies wildly (Fig. 1C) suggesting that the disparate physicochemical environments between coral species may favour divergent pathways. Multiple authors proposed that denitrification may present a meaningful pathway for $\mathrm{N}$ release from the coral holobiont under eutrophic stress $[13,46]$. The rates presented here, and their relative contribution to TDN release $(0.07 \%)$ infer $\mathrm{N}_{2}$ production is of limited functional importance to the coral holobiont. We would expect the relatively eutrophic conditions under which these incubations were performed to stimulate denitrification activity given the increased availability of substrate. Even these negligible values may therefore overestimate denitrification rates expected under typical OTI lagoon DIN concentrations. The limited importance of denitrification is reinforced by the captured metagenomics analysis on $P$. cylindrica, which indicates that the specific microbes possessing napA/narG are predominantly capable of DNRA, not denitrification. We also detected a relatively low proportion of nirs, nirk, norB and nos $Z$ genes, with no organism identified as possessing a full suite of denitrifying genes (Fig. 6). Coral-associated denitrification is therefore likely an opportunistic response to the availability of inorganic $\mathrm{N}$, rather 

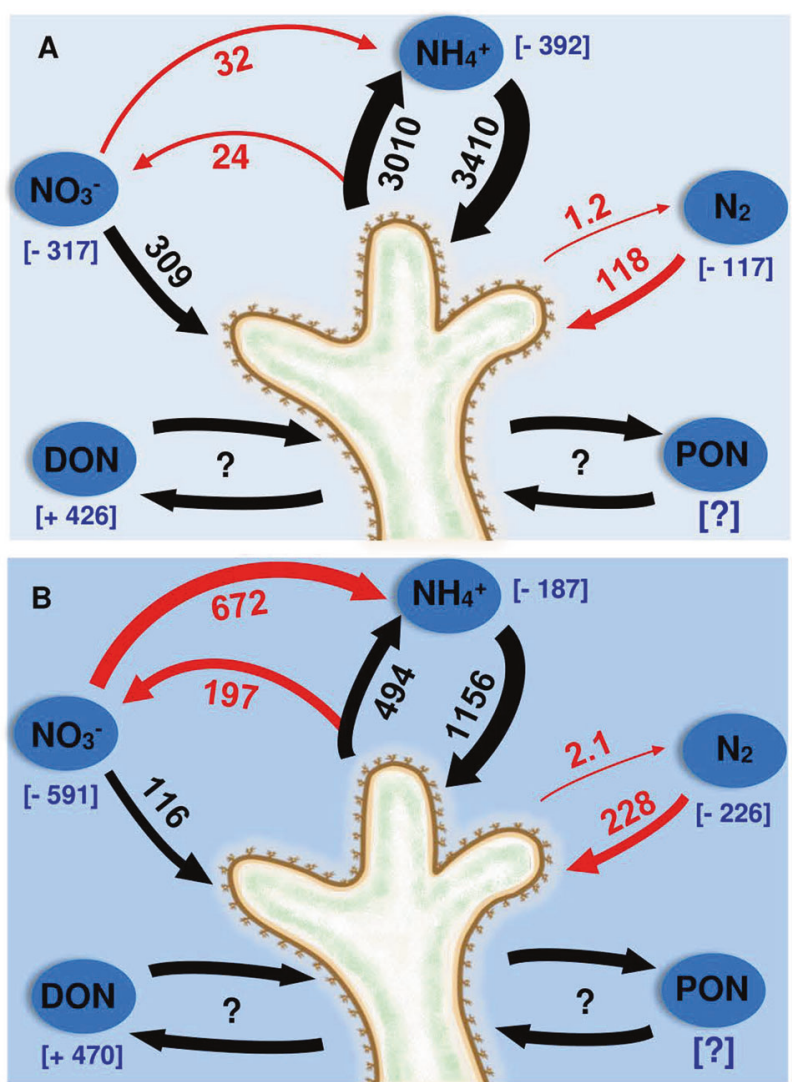

Fig. 7 Compiled coral holobiont $\mathbf{N}$-cycling processes and budget. Representative mass balance, displaying the magnitude of measured $\mathrm{N}$-cycling pathways operating within live corals. Black arrows and values denote coral/Symbiodiniaceae pathways. Red arrows/ values denote other microbially facilitated pathways. Blue values in square brackets denote net fluxes of respective substrates. All values are in $\mu \mathrm{mol} \mathrm{N} \mathrm{m}{ }^{-2} \mathrm{~d}^{-1}$. A Coral $\mathrm{N}$-cycling under light conditions. B Coral $\mathrm{N}$-cycling under dark conditions.

than intrinsically important in the regulation of $\mathrm{N}$ availability (Fig. 7).

Nitrification activity was recorded in all species tested at One Tree Island. This aligns with the current literature, which suggest that coral nitrifying organisms may be ubiquitous, occurring in the mucus, tissue, skeleton and in interstitial spaces between branches [19, 46, 48]. Previous studies suggest that coralassociated nitrification activity would primarily be active during day light, when the DO saturation state of coral mucus is suitable for aerobic processes such as nitrification to occur [46]. Conversely, we find clear upregulation of dark nitrification activity across all species. This may be the result of the photoinhibitory effects of high light intensity breaching the light tolerance thresholds of the nitrifying organisms present [49]. Ammoniaoxidizing archaea (AOA) are especially susceptible to photoinhibition, providing further putative evidence that $A O A$ are the dominant coral-associated ammonia oxidizers $[43,50]$.

Previous coral nitrification measurements outlined significant gross nitrification activity, equating to $17 \% \mathrm{NH}_{4}{ }^{+}$assimilation values under dark conditions [19]. The net nitrification values we present in this study are considerably lower, equating to $0.01 \%$ and $0.4 \%$ of $\mathrm{NH}_{4}{ }^{+}$assimilation under light and dark scenarios, respectively. While these dissimilar outcomes may be the result of methodological differences, or regional/interspecies variability, findings may still be consistent between studies. The highly enriched $\delta^{15} \mathrm{~N}_{-} \mathrm{NO}_{3}{ }^{-}$of the nitrate pool following ${ }^{15} \mathrm{~N}_{-} \mathrm{NH}_{4}{ }^{+}$ incubation suggests that $\mathrm{NO}_{3}{ }^{-}$consuming processes such as

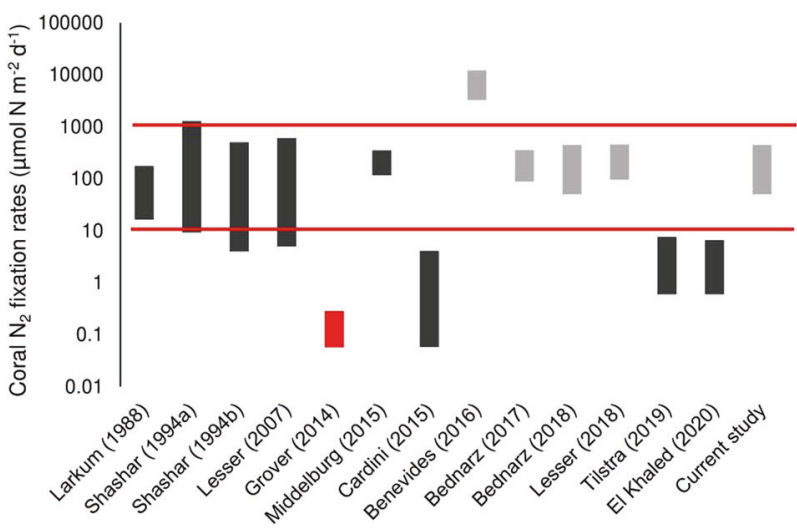

Fig. 8 Approximate range of coral-associated $\mathrm{N}_{2}$ fixation values from recent articles, converted from a wide range of units to $\boldsymbol{\mu m o l} \mathbf{N ~ m}^{-2} \mathbf{d}^{-1}$. Dark grey bars represent studies, which used the acetylene reduction technique. Light grey bars represent studies, which used ${ }^{15} \mathrm{~N}_{2}$ tracer incubations. The study conducted by Grover et al. [59] has been filled red as it used the buddle dissolution technique for preparation of ${ }^{15} \mathrm{~N}_{2}$ stock solution, which considerably underestimates $\mathrm{N}_{2}$ fixation.

$\mathrm{NO}_{3}{ }^{-}$assimilation, denitrification and DNRA may be masking high gross nitrification activity through consumption of nitrified $\mathrm{NO}_{3}{ }^{-}$. In addition, nutrient diffusion rates between the water column and endolithic nitrifiers may also obfuscate nitrification measurements. Nutrient diffusion rates similar to that of photoassimilates (24-48 h) may fall outside the incubation window, subsequently underestimating nitrification activity [51]. The true magnitude of gross nitrification in this study is therefore difficult to accurately determine, nevertheless it is clear that nitrified $\mathrm{NO}_{3}{ }^{-}$is rapidly recycled.

Despite clear biogeochemical evidence of active nitrification, $a m o A$ and hao functional gene markers were not detected and could not be quantified in $P$. cylindrica. Given the high $\delta^{15} \mathrm{~N}-\mathrm{NO}_{3}$ enrichment level, and prior molecular evidence of coral-associated nitrification $[43,44,46]$, we assume that $a m o A$ and hao are likely present, but remain undetected due to technical/methodological reasons, such as the specificity or sensitivity of the captured metagenomics probe.

\section{$\mathbf{N}_{2}$ fixation}

Diazotrophs have previously been confirmed to reside in the coral mucus, tissue and skeleton microhabitats [52-56]. We find that $\mathrm{N}_{2}$ fixation is a ubiquitous feature of coral microbiomes, occurring in all coral species tested under both light and dark scenarios, which agrees with much of the previous research $[1,18,57-59]$. DDN has been repeatedly demonstrated as a significant $\mathrm{N}$ source for the coral host and Symbiodiniaceae [32, 53,60]. Assimilation rates of DDN were substantial, and would potentially be greater still under standard OTI lagoon DIN concentrations, as elevated DIN can reduce or inhibit $\mathrm{N}_{2}$ fixation activity [61]. Relative to $\mathrm{NH}_{4}{ }^{+}$ assimilation, our reported $\mathrm{N}_{2}$ fixation rates may seem a modest contribution to TDN input; however, $\mathrm{N}_{2}$ net flux represents a significant share of the TDN net flux, suggesting that $\mathrm{N}_{2}$ fixation provides a disproportionate contribution to the coral $\mathrm{N}$ budget than DDN assimilation rates alone would imply (Fig. 4).

Our $\mathrm{N}_{2}$ fixation results compare favourably with most studies, which have utilized the ${ }^{15} \mathrm{~N}_{2}$ dissolution technique [31, 60, 62], and many which utilized acetylene reduction assays [52, 53, 63, 64] (Fig. 8). We find considerable overlap with Lesser et al. [31], which presents a similar range of $\mathrm{N}_{2}$ fixation values in the analogous high light, 5-m depth coral incubations $\left(\sim 220 \mu \mathrm{mol} \mathrm{N} \mathrm{m}{ }^{-2} \mathrm{~d}^{-1}\right)$ as those presented here $\left(54-320 \mu \mathrm{mol} \mathrm{N} \mathrm{m} \mathrm{d}^{-1}\right)$. Lesser found no influence of light regime on DDN assimilation rates, which aligns with five of the six coral species tested at One Tree Island. The 
community composition of identified diazotrophs also has parallels with previous studies, with abundant proteobacteria and little evidence of cyanobacteria [31, 57,65]. With regard to net fluxes of bioavailable $\mathrm{N}$, defined as the relative magnitudes of $\mathrm{N}_{2}$ fixing vs. $\mathrm{N}_{2}$ releasing processes, our study diverges with the available literature $[20,45]$. Tilstra et al. [20] and El-Khaled et al. [45] report that the $\mathrm{N}_{2}$ net flux from coral holobionts is effectively nil, as $\mathrm{N}_{2}$ fixation and $\mathrm{N}_{2}$ production processes are balanced. While denitrification values are equivalent across studies, $\mathrm{N}_{2}$ fixation values reported in Tilstra and El-Khaled are $\sim 2$ orders of magnitude lower than most reported rates (Fig. 8). In light of this, we propose that $\mathrm{N}_{2}$ fixation provides an important $\mathrm{N}$ source to living corals, and determine through comparison with $\mathrm{N}_{2}$ production, coral holobionts are net $\mathrm{N}$ importers to coral reef systems under most scenarios (Fig. 7).

\section{DNRA}

Elevated $\mathrm{NO}_{3}{ }^{-}$availability in coral reefs $[66,67]$ coupled with more favourable uptake kinetics prompted earlier researchers to infer that $\mathrm{NO}_{3}{ }^{-}$is the dominant DIN species incorporated into coral biomass [66]. However, studies tracing gross assimilation of $\mathrm{NH}_{4}{ }^{+}$ and $\mathrm{NO}_{3}{ }^{-}$into coral tissue report that $\mathrm{NH}_{4}{ }^{+}$is disproportionately assimilated at a rate 1-2 orders of magnitude above $\mathrm{NO}_{3}{ }^{-}$ $[39,40,60]$. In our light incubations, $\mathrm{NH}_{4}^{+}$assimilation is tenfold greater than net $\mathrm{NO}_{3}{ }^{-}$uptake, consistent with Grover, implying gross $\mathrm{NO}_{3}{ }^{-}$assimilation and net uptake may be synonymous. Under dark conditions, $\mathrm{NH}_{4}{ }^{+}$assimilation was downregulated, while $\mathrm{NO}_{3}{ }^{-}$net flux was simultaneously upregulated, providing a ratio of 2:1 and indicating gross $\mathrm{NO}_{3}{ }^{-}$assimilation and net uptake are likely uncoupled. While it is possible that $\mathrm{NO}_{3}{ }^{-}$assimilation upregulates under typical night time environmental conditions, this seems unlikely as coral $\mathrm{NO}_{3}{ }^{-}$demand is driven by photosynthetic Symbiodiniaceae activity. A more parsimonious explanation is that another $\mathrm{NO}_{3}{ }^{-}$consumption process is active at night, such as DNRA.

In the current study, DNRA activity provides a neat explanation for dark upregulation of net $\mathrm{NO}_{3}{ }^{-}$uptake, and the absence of $\mathrm{NO}_{3}{ }^{-}$uptake inhibition, the usual response to $\mathrm{NH}_{4}{ }^{+}$availability $[40,68]$. Records of ${ }^{15} \mathrm{~N}$ enrichment in the animal tissue fraction following ${ }^{15} \mathrm{NO}_{3}{ }^{-}$incubation experiments have perplexed authors, given the absence of the requisite nitrate reductase genes in coral hosts $[40,69]$. We posit that ${ }^{15} \mathrm{NO}_{3}{ }^{-}$is converted into ${ }^{15} \mathrm{NH}_{4}{ }^{+}$ through DNRA and subsequently assimilated into coral biomass in these cases. DNRA activity in coral holobionts is likely beneficial for coral fitness and function through reducing $\mathrm{N}$ limitation via the conversion of the more readily available DIN form $\left(\mathrm{NO}_{3}{ }^{-}\right)$, to the more favourable and rapidly assimilable form $\left(\mathrm{NH}_{4}{ }^{+}\right)$. The Vibrio taxa predominantly responsible for coral-associated DNRA may be not only physiologically relevant for the coral $\mathrm{N}$ budget, but also provide protection from thermal stress through altering the DIN composition [70], juxtaposing the disease and bleaching response associated with Vibrio lineages [71-73].

Multiple lines of evidence indicate potential DNRA activity. First, DNRA activity is substantiated by the relatively high nrfA and napA gene copy numbers measured here in $P$. cylindrica, and prior records of $n r f A$ in $P$. astreoides [3]. The relatively high ratio of $n r f A$ to nos $Z$ we observed are also a key indicator of potential DNRA activity [42]. In addition, the environmental conditions present in corals at night provide suitable criteria to facilitate DNRA. Significant DNRA activity has already been demonstrated in coral reef sediments [74], and the conditions which stimulate DNRA and permit it to outcompete denitrification are numerous on living coral surfaces. DNRA activity favours hypoxic to anoxic boundary conditions, limited nitrate compared with organic carbon [75, 76], and high salinity and temperature $[77,78]$, all of which occur in coral tissue, mucus and skeletons at night [27-30, 79]. If DNRA activity is operating at the scale described in the mass balance model $\left(460-780 \mu \mathrm{mol} \mathrm{N} \mathrm{m}{ }^{-2} \mathrm{~d}^{-1}\right)$, this presents a significant $\mathrm{N}$ retention mechanism under dark conditions, functioning as the principal pathway of $\mathrm{NO}_{3}{ }^{-}$depletion and contributing $\sim 40-70 \%$ of the available $\mathrm{NH}_{4}{ }^{+}$for assimilation (Fig. 7B).

\section{CONCLUSION}

A diverse and dynamic $\mathrm{N}$-cycling community is evidently a ubiquitous feature of the coral holobiont. Here we provide some of the first direct evidence that denitrification is active in living corals, although rates were low with respect to coral physiology and reef biogeochemistry (Fig. 7A, B). In addition, we present evidence of nitrification activity, positing recorded net nitrification rates likely underestimate gross nitrification activity. Importantly, we provide strong evidence that DNRA is an active $\mathrm{N}$-cycling pathway in tropical corals, contributing a substantial component of assimilated $\mathrm{NH}_{4}{ }^{+}$under dark conditions (Fig. 7B), and thereby operating at environmentally relevant scales. Finally, we corroborate the findings of earlier researchers, which highlight the importance of $\mathrm{N}_{2}$ fixation to coral $\mathrm{N}$ demand, and further identify corals as net $\mathrm{N}$ importers to reef systems (Fig. 7A, B). We advise readers exercise caution when applying the $\mathrm{N}$-cycling rates presented herein to corals more broadly. We found high intraspecies and intracolony variability across many $\mathrm{N}$-cycling processes, and markedly different patterns of activity between processes. Corals are heterogenous and dynamic systems, and further research is required to determine the relevant variables underpinning such variability.

\section{REFERENCES}

1. Rohwer F, Breitbart M, Jara J, Azam F, Knowlton N. Diversity of bacteria associated with the Caribbean coral Montastraea franksi. Coral Reefs. 2001;20:85-91.

2. Kellogg CA. Tropical Archaea: diversity associated with the surface microlayer of corals. Mar Ecol Prog Ser. 2004;273:81-8.

3. Wegley L, Edwards R, Rodriguez-Brito B, Liu H, Rohwer F. Metagenomic analysis of the microbial community associated with the coral Porites astreoides. Environ Microbiol. 2007;9:2707-19.

4. Thurber RV, Payet JP, Thurber AR, Correa AMS. Virus-host interactions and their roles in coral reef health and disease. Nat Rev Microbiol. 2017;15:205-16.

5. Siboni N, Rasoulouniriana D, Ben-Dov E, Kramarsky-Winter E, Sivan A, Loya Y, et al. Stramenopile microorganisms associated with the massive coral favia sp. J Eukaryot Microbiol. 2010;57:236-44.

6. Harvell CD. Emerging marine diseases-climate links and anthropogenic factors. Science. 1999:285:1505-10.

7. Reshef L, Koren O, Loya Y, Zilber-Rosenberg I, Rosenberg E. The coral probiotic hypothesis. Environ Microbiol. 2006;8:2068-73.

8. Ainsworth TD, Thurber RV, Gates RD. The future of coral reefs: a microbial perspective. Trends Ecol Evol. 2010;25:233-40.

9. Welsh RM, Rosales SM, Zaneveld JR, Payet JP, McMinds R, Hubbs SL, et al. Alien vs. predator: bacterial challenge alters coral microbiomes unless controlled by Halobacteriovorax predators. PeerJ. 2017;5:e3315.

10. Rosenberg E, Koren O, Reshef L, Efrony R, Zilber-Rosenberg I. The role of microorganisms in coral health, disease and evolution. Nat Rev Microbiol. 2007;5:355-62.

11. Kimes NE, Van Nostrand JD, Weil E, Zhou J, Morris PJ. Microbial functional structure of Montastraea faveolata, an important Caribbean reef-building coral differs between healthy and yellow-band diseased colonies. Environ Microbiol. 2010;12:541-56.

12. Raina JB, Tapiolas D, Willis BL, Bourne DG. Coral-associated bacteria and their role in the biogeochemical cycling of sulfur. Appl Environ Microbiol. 2009;75:3492-501.

13. Rädecker N, Pogoreutz C, Voolstra CR, Wiedenmann J, Wild C. Nitrogen cycling in corals: the key to understanding holobiont functioning? Trends Microbiol. 2015;23:490-7.

14. Pogoreutz C, Rädecker N, Cárdenas A, Gärdes A, Wild C, Voolstra CR. Nitrogen fixation aligns with nifH abundance and expression in two coral trophic functional groups. Front Microbiol. 2017;8:1-7.

15. Falkowski PG, Dubinsky Z, Muscatine L, McCloskey L. Population control in symbiotic corals. Bioscience. 1993;43:606-11.

16. Falkowski PG. Evolution of the nitrogen cycle and its influence on the biological sequestration of $\mathrm{CO}_{2}$ in the ocean. Nature. 1997;387:272-5.

17. Tyrrell $\mathrm{T}$. The relative influences of nitrogen and phosphorus on oceanic primary production. Nature. 1999;400:525-31. 
18. Lesser MP, Mazel CH, Gorbunov MY, Falkowski PG. Discovery of symbiotic nitrogen fixing cyanobacteria in coral. Science. 2004;997:997-1000.

19. Wafar MM, Wafar S, David JJ. Nitrification in reef corals. Limnol Oceanogr. 1990;35:725-30.

20. Tilstra A, El-Khaled $Y C$, Roth $F$, Rädecker N, Pogoreutz $C$, Voolstra $C R$, et al. Denitrification aligns with $\mathrm{N}_{2}$ fixation in Red Sea corals. Sci Rep. 2019;9:1-9.

21. Beraud $E$, Gevaert $F$, Rottier $C$, Ferrier-Pagès $C$. The response of the scleractinian coral Turbinaria reniformis to thermal stress depends on the nitrogen status of the coral holobiont. J Exp Biol. 2013;216:2665-74.

22. Dubinsky Z, Jokiel PL. Ratio of energy and nutrient fluxes regulates symbiosis between zooxanthellae and corals. Pacific Sci. 1994;48:313-24.

23. Rädecker N, Pogoreutz C, Ziegler M, Ashok A, Barreto MM, Chaidez V, et al. Assessing the effects of iron enrichment across holobiont compartments reveals reduced microbial nitrogen fixation in the Red Sea coral Pocillopora verrucosa. Ecol Evol. 2017;7:6614-21.

24. Middelburg JJ, Mueller CE, Veuger B, Larsson Al, Form A, Van Oevelen D. Discovery of symbiotic nitrogen fixation and chemoautotrophy in cold-water corals. Sci Rep. 2015;5:1-9.

25. Zhang $Y$, Ling J, Yang $Q$, Wen $C$, Yan $Q$, Sun $H$, et al. The functional gene composition and metabolic potential of coral-associated microbial communities. Sci Rep. 2015;5:16191.

26. Bourne DG, Morrow KM, Webster NS. Insights into the coral microbiome: underpinning the health and resilience of reef ecosystems. Annu Rev Microbiol. 2016;70:317-40.

27. Thompson JR, Rivera HE, Closek CJ, Medina M. Microbes in the coral holobiont: partners through evolution, development, and ecological interactions. Front Cell Infect Microbiol. 2015;4:1-20.

28. Agostini S, Suzuki Y, Higuchi T, Casareto BE, Yoshinaga K, Nakano Y, et al. Biological and chemical characteristics of the coral gastric cavity. Coral Reefs. 2012;31:147-56.

29. Bythell JC, Wild C. Biology and ecology of coral mucus release. J Exp Mar Bio Ecol. 2011;408:88-93.

30. Shashar N, Banaszak AT, Lesser MP, Amrami D. Coral endolithic algae: life in a protected environment. Pacific Sci. 1997;51:167-73.

31. Lesser MP, Morrow KM, Pankey SM, Noonan SHC. Diazotroph diversity and nitrogen fixation in the coral Stylophora pistillata from the Great Barrier Reef. ISME J. 2018;12:813-24.

32. Benavides $M$, Houlbrèque $F$, Camps $M$, Lorrain $A$, Grosso $O$, Bonnet $S$. Diazotrophs: a non-negligible source of nitrogen for the tropical coral Stylophora pistillata. J Exp Biol. 2016:jeb.139451. https://doi.org/10.1242/jeb.139451.

33. Koop K, Booth D, Broadbent A, Brodie JE, Bucher D, Capone DG, et al. ENCORE: the effect of nutrient enrichment on coral reefs. Synthesis of results and conclusions. Mar Pollut Bull. 2001;42:91-120.

34. Hatcher $\mathrm{Al}$, Hatcher BG. Seasonal and spatial variation in dissolved inorganic nitrogen in the one tree reef lagoon. Proc 4th Int Coral Reef Symp. 1981;1:419-24.

35. Mohr W, Großkopf T, Wallace DWR, LaRoche J. Methodological underestimation of oceanic nitrogen fixation rates. PLoS ONE. 2010;5:1-7.

36. Lewicka-Szczebak $D$, Well $R$, Giesemann $A$, Rohe $L$, Wolf $U$. An enhanced technique for automated determination of ${ }^{15} \mathrm{~N}$ signatures of $\mathrm{N}_{2},\left(\mathrm{~N}_{2}+\mathrm{N}_{2} \mathrm{O}\right)$ and $\mathrm{N}_{2} \mathrm{O}$ in gas samples. Rapid Commun Mass Spectrom. 2013;27:1548-58.

37. Sigman DM, Casciotti KL, Andreani M, Barford C, Galanter M, Böhlke JK. A bacterial method for the nitrogen isotopic analysis of nitrate in seawater and freshwater. Anal Chem. 2001;73:4145-53.

38. Montoya JP, Voss M, Kahler P, Capone DG. A simple, high-precision, highsensitivity tracer assay for $\mathrm{N}_{2}$ fixation. Appl Environ Microbiol. 1996;62:986-93.

39. Grover R, Maguer JF, Reynaud-Vaganay S, Ferrier-Pagès C. Uptake of ammonium by the scleractinian coral Stylophora pistillata: effect of feeding, light, and ammonium concentrations. Limnol Oceanogr. 2002;47:782-90.

40. Grover R, Maguer JF, Allemand D, Ferrier-Pagès $C$. Nitrate uptake in the scleractinian coral Stylophora pistillata. Limnol Oceanogr. 2003;48:2266-74.

41. Aalto SL, Suurnäkki S, von Ahnen M, Siljanen HMP, Pedersen PB, Tiirola M. Nitrate removal microbiology in woodchip bioreactors: a case-study with full-scale bioreactors treating aquaculture effluents. Sci Total Environ. 2020;723:138093.

42. Pandey CB, Kumar U, Kaviraj M, Minick KJ, Mishra AK, Singh JS. DNRA: a shortcircuit in biological $\mathrm{N}$-cycling to conserve nitrogen in terrestrial ecosystems. Sci Total Environ. 2020;738:139710.

43. Beman JM, Roberts KJ, Wegley L, Rohwer F, Francis CA. Distribution and diversity of archaeal ammonia monooxygenase genes associated with corals. Appl Environ Microbiol. 2007;73:5642-7.

44. Yang S, Sun W, Zhang F, Li Z. Phylogenetically diverse denitrifying and ammoniaoxidizing bacteria in corals Alcyonium gracillimum and Tubastraea coccinea. Mar Biotechnol. 2013;15:540-51.

45. El-Khaled YC, Roth F, Tilstra A, Rädecker N, Karcher DB, Kürten B, et al. In situ eutrophication stimulates dinitrogen fixation, denitrification, and productivity in Red Sea coral reefs. Mar Ecol Prog Ser. 2020;645:55-66.
46. Siboni N, Ben-Dov E, Sivan A, Kushmaro A. Global distribution and diversity of coral-associated archaea and their possible role in the coral holobiont nitrogen cycle. Environ Microbiol. 2008;10:2979-90.

47. Shashar N, Cohen Y, Loya Y. Extreme diel fluctuations of oxygen in diffusive boundary layers surrounding stony corals. Biol Bull. 1993;185:455-61.

48. Risk MJ, Muller HR. Poreweater in coral heads: evidence for nutrient regeneration. Limnol Oceanogr. 1983;28:1004-8.

49. Guerrero MA, Jones RD. Photoinhibition of marine nitrifying bacteria. II. Dark recovery after monochromatic or polychromatic irradiation. Mar Ecol Prog Ser. 1996;141:193-8.

50. Merbt SN, Stahl DA, Casamayor EO, Martí E, Nicol GW, Prosser Jl. Differential photoinhibition of bacterial and archaeal ammonia oxidation. FEMS Microbiol Lett. 2012;327:41-6.

51. Pernice M, Raina JB, Rädecker N, Cárdenas A, Pogoreutz C, Voolstra CR. Down to the bone: the role of overlooked endolithic microbiomes in reef coral health. ISME J. 2020;14:325-34.

52. Shashar N, Cohen $Y$, Loya $Y$, Sar N. Nitrogen fixation (acetylene reduction) in stony corals-evidence for coral-bacteria interactions. Mar Ecol Prog Ser. 1994;111:259-64.

53. Lesser MP, Falcón LI, Rodríguez-Román A, Enríquez S, Hoegh-Guldberg O, Iglesias-Prieto R. Nitrogen fixation by symbiotic cyanobacteria provides a source of nitrogen for the scleractinian coral Montastraea cavernosa. Mar Ecol Prog Ser. 2007;346:143-52.

54. Lema KA, Willis BL, Bourne DG. Corals form characteristic associations with symbiotic nitrogen-fixing bacteria. Appl Environ Microbiol. 2012;78:3136-44.

55. Crossland CJ, Barnes DJ. Acetylene reduction by coral skeletons. Limnol Oceanogr. 1976;21:153-6.

56. Cai L, Zhou G, Tian R-M, Tong H, Zhang W, Sun J, et al. Metagenomic analysis reveals a green sulfur bacterium as a potential coral symbiont. Sci Rep. 2017;7:9320.

57. Olson ND, Ainsworth TD, Gates RD, Takabayashi M. Diazotrophic bacteria associated with Hawaiian Montipora corals: diversity and abundance in correlation with symbiotic dinoflagellates. J Exp Mar Bio Ecol. 2009;371:140-6.

58. Cardini U, Bednarz VN, Naumann MS, van Hoytema N, Rix L, Foster RA, et al. Functional significance of dinitrogen fixation in sustaining coral productivity under oligotrophic conditions. Proc R Soc B Biol Sci. 2015;282:20152257.

59. Grover R, Ferrier-Pagès $C$, Maguer JF, Ezzat L, Fine $M$. Nitrogen fixation in the mucus of Red Sea corals. J Exp Biol. 2014;217:3962-3.

60. Bednarz VN, Grover R, Maguer JF, Fine M. The assimilation of diazotroph-derived nitrogen by scleractinian corals. Amer Soc Microbiol. 2017;8:1-14.

61. Knapp AN. The sensitivity of marine $\mathrm{N}_{2}$ fixation to dissolved inorganic nitrogen. Front Microbiol. 2012;3:1-14.

62. Bednarz VN, Naumann MS, Cardini U, van Hoytema N, Rix L, Al-Rshaidat MMD, et al. Contrasting seasonal responses in dinitrogen fixation between shallow and deep-water colonies of the model coral Stylophora pistillata in the northern Red Sea. PLoS ONE. 2018;13:e0199022.

63. Larkum AWD, Kennedy IR, Muller WJ. Nitrogen fixation on a coral reef. Mar Biol. 1988;98:143-55.

64. Shashar N, Feldstein T, Cohen Y, Loya Y. Nitrogen fixation (acetylene reduction) on a coral reef. Coral Reefs. 1994;13:171-4.

65. Santos HF, Carmo FL, Duarte G, Dini-Andreote F, Castro CB, Rosado AS, et al. Climate change affects key nitrogen-fixing bacterial populations on coral reefs. ISME J. 2014;8:2272-9.

66. Bythell JC. Nutrient uptake in the reef-building coral Acropora palmata at natural environmental concentrations. Mar Ecol Prog Ser. 1990;68:65-9.

67. Furnas MJ. Net in situ growth rates of phytoplankton in an oligotrophic, tropical shelf ecosystem. Limnol Oceanogr. 1991;36:13-29.

68. Badgley BD, Lipschultz F, Sebens KP. Nitrate uptake by the reef coral Diploria strigosa: effects of concentration, water flow, and irradiance. Mar Biol. 2006;149:327-38.

69. Tanaka Y, Miyajima T, Koike I, Hayashibara T, Ogawa H. Translocation and conservation of organic nitrogen within the coral-zooxanthella symbiotic system of Acropora pulchra, as demonstrated by dual isotope-labeling techniques. J Exp Mar Bio Ecol. 2006;336:110-9.

70. Fernandes de Barros Marangoni L, Ferrier-Pagès C, Rottier C, Bianchini A, Grover R. Unravelling the different causes of nitrate and ammonium effects on coral bleaching. Sci Rep. 2020;10:1-14.

71. Munn CB. The role of vibrios in diseases of corals. Microbiol Spectr. 2015;3: $1-12$.

72. Rubio-Portillo E, Gago JF, Martínez-García M, Vezzulli L, Rosselló-Móra R, Antón J, et al. Vibrio communities in scleractinian corals differ according to health status and geographic location in the Mediterranean Sea. Syst Appl Microbiol. 2018;41: 131-8.

73. Tout J, Siboni N, Messer LF, Garren M, Stocker R, Webster NS, et al. Increased seawater temperature increases the abundance and alters the structure of 
natural Vibrio populations associated with the coral Pocillopora damicornis. Front Microbiol. 2015;6:1-12.

74. Erler DV, Santos IR, Eyre BD. Inorganic nitrogen transformations within permeable carbonate sands. Cont Shelf Res. 2014;77:69-80.

75. Tiedje JM, Sexstone AJ, Myrold DD, Robinson JA. Denitrification: ecological niches, competition and survival. Antonie Van Leeuwenhoek. 1983;48:569-83.

76. Stremińska MA, Felgate H, Rowley G, Richardson DJ, Baggs EM. Nitrous oxide production in soil isolates of nitrate-ammonifying bacteria. Environ Microbiol Rep. 2012;4:66-71.

77. Gardner WS, McCarthy MJ, An S, Sobolev D, Sell KS, Brock D. Nitrogen fixation and dissimilatory nitrate reduction to ammonium (DNRA) support nitrogen dynamics in Texas estuaries. Limnol Oceanogr. 2006;51:558-68.

78. Giblin AE, Weston NB, Banta GT, Tucker J, Hopkinson CS. The effects of salinity on nitrogen losses from an oligohaline estuarine sediment. Estuaries Coasts. 2010;33:1054-68.

79. Giblin AE, Tobias CR, Song B, Weston N, Banta GT, Rivera-Monroy VH. The importance of dissimilatory nitrate reduction to ammonium (DNRA) in the nitrogen cycle of coastal ecosystems. Oceanography. 2013;26:124-31.

\section{ACKNOWLEDGEMENTS}

This work was supported by the Australian Research Council Discovery Project Grant (DP170100734). We would like to thank A. McMahon and K. Davis (SCU) for assistance with sampling and incubations and J. Wolstenholme for guidance on taxonomy. I. Alexander, N. Carlson-Perret, H.T. Farid and M. Carvalho were also involved with laboratory analysis.

\section{AUTHOR CONTRIBUTIONS}

TDG and DVE were responsible for coral sampling and incubations. Sample analysis was conducted by TDG. Captured metagenomics were conducted by HMPS. The manuscript was written by TDG in collaboration with all authors.

\section{COMPETING INTERESTS}

The authors declare no competing interests.

\section{ADDITIONAL INFORMATION}

Supplementary information The online version contains supplementary material available at https://doi.org/10.1038/s41396-021-01038-1.

Correspondence and requests for materials should be addressed to T.D.G.

Reprints and permission information is available at http://www.nature.com/ reprints

Publisher's note Springer Nature remains neutral with regard to jurisdictional claims in published maps and institutional affiliations.

(i) Open Access This article is licensed under a Creative Commons Attribution 4.0 International License, which permits use, sharing, adaptation, distribution and reproduction in any medium or format, as long as you give appropriate credit to the original author(s) and the source, provide a link to the Creative Commons license, and indicate if changes were made. The images or other third party material in this article are included in the article's Creative Commons license, unless indicated otherwise in a credit line to the material. If material is not included in the article's Creative Commons license and your intended use is not permitted by statutory regulation or exceeds the permitted use, you will need to obtain permission directly from the copyright holder. To view a copy of this license, visit http://creativecommons. org/licenses/by/4.0/.

(c) The Author(s), under exclusive licence to International Society for Microbial Ecology 2021 